\title{
Agricultural credit use in papaya agroecosystems in the central region of Veracruz, Mexico
}

\author{
Zarrabal-Prieto, Alba A. ${ }^{1}$; García-Pérez, Eliseo ${ }^{1 *}$; Ávila-Reséndiz, Catarino ${ }^{1}$; Escobedo-Garrido, José S. ${ }^{2}$ \\ ${ }^{1}$ Colegio de Postgraduados, Campus Veracruz, Manlio Fabio Altamirano, Veracruz, Mexico. \\ ${ }^{2}$ Colegio de Postgraduados, Campus Puebla, Santiago Momoxpan, San Pedro Cholula, Puebla, \\ México
}

*Corresponding author: geliseo@colpos.mx

\begin{abstract}
Objective: To analyze the use of agricultural credit and the profitability of their papaya agroecosystem.

Design/methodology/approach: A survey was applied using a questionnaire to 114 producers in seven municipalities in the central area of Veracruz, Mexico.

Results: $75 \%$ of papaya growers do not know about formal sources of credit that support their productive activity. Only $22.8 \%$ have used some type of financing, and only $2.6 \%$ came from formal credit sources, even though, $97.4 \%$ used semiformal and informal financing options. $77.2 \%$ of growers use their own economic resources for papaya production. This generates a great heterogeneity on production costs and crop management (level of technology) that reflects the final yield. Even under these conditions the crop is profitable.

Limitations of the study/implications: Information from public or private credit institutions, does not reach potential users. The few farmers who have accessed a formal credit, have had bad experiences, such as embargoes and legal actions due to special situations that made them not paying on time, that discourage growers from using this type of credit.

Findings/Conclusions: Lack of knowledge of the growers about financing sources. Low use of agricultural or other formal private credits, as $77.2 \%$ of growers used their own economic resources, which generates great heterogeneity in production costs associated with the level of technology, that is reflected in the crop yield, even so the papaya crop still is profitable.
\end{abstract}

Keywords: Carica papaya, farmer credits, production costs, yield, profitability.

\section{INTRODUCTION}

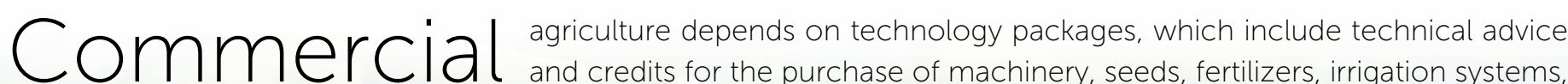
herbicides, pesticides and other inputs, although this agriculture has negative effects on the environment and human health from the ecology viewpoint, their contribution to world food production cannot be denied (FAO, 2009).

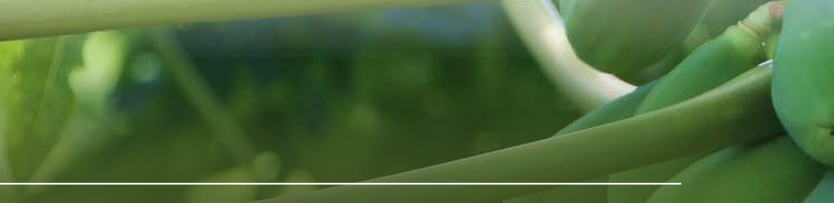

Agroproductividad: Vol. 14, Núm. 4, abril. 2021. pp: 53-58. Recibido: noviembre, 2020. Aceptado: abril, 2021.

Imagen de Juan Carlos Torrico en Pixabay

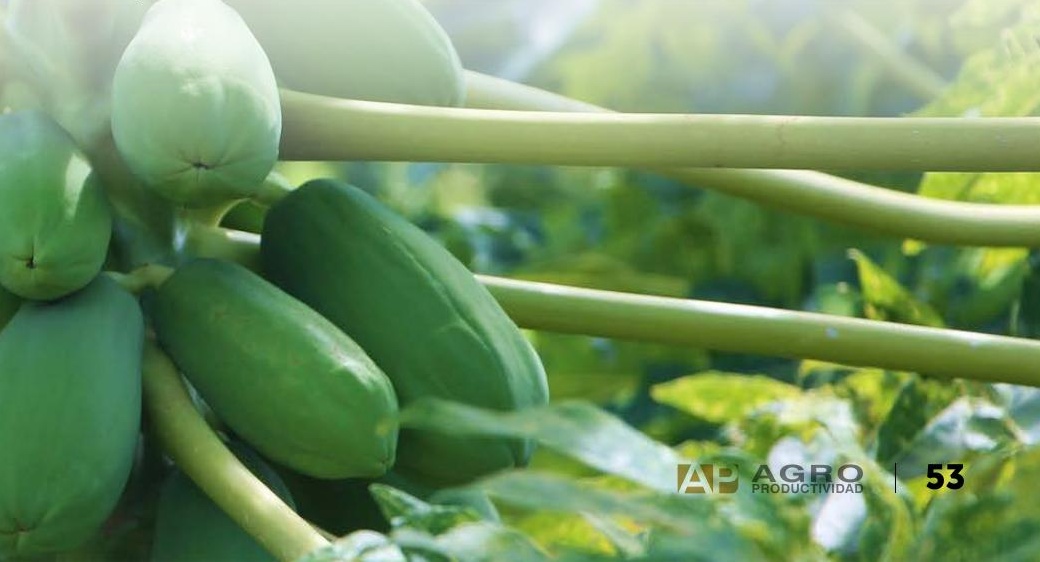


In Mexico, the banking system comprises the multiple banking system and development bank system. As of 2002, the creation of Bancos Asociados a Cadenas Comerciales (BACC) was authorized. It was considered to be a multiple banking institution (SHCP, 2012). As of late 2002 to early 2014, as a de-centralized body of the Federal Public Administration, Rural Financing (FR) is the Federal Government's official agency that encourages agriculture and livestock raising, forest, fishing and all other activities linked to the rural environment, as well as the formation of first-floor financial intermediaries (SHCP, 2009).

According to Carranza (2007), financing sources by which agriculture and livestock raising producer get resources from may be classified as domestic and foreign, as well as formal (banking and non-banking), semi-formal (cooperation, producer organization) and informal (local lenders, loan sharks and usurers), credit from agents from inside the production chain (input producers, final product purchasers) and friend and family credit.

As papaya is a fully commercial crop, completely addressed to the market, it shows certain technical demands for its production process in order to reach performance and quality required by the market. Small producers in the state of Veracruz try to incorporate innovations such as fertilization and pests combat, which represents strong amounts of money for their purchase and application; also, the fruit's growth requires a major amount of contracted labor. These items mean major expenses for the producer who does not have access to financing sources, with amounts, periods and interest rates adequate for their activity.

Mexico falls on fifth place as a papaya producer at a world level, with a production of around 961,768 t in year 2017; it is also one of the main exporting countries with around 168 mil t, 99\% of which are bound for the US. In order of importance, exporter countries that follow are Brazil, Belize, Malasia and India (FAOSTAT, 2017). The Agroalimentary and Fishing Information System (SIAP) reports that there is papaya production in 20 states of Mexico, of which Veracruz, Michoacán, Colima, Oaxaca, Chiapas and Guerrero stand out by their sown area, which concentrate more than $73 \%$ of sown surface with 19,845 ha, with a production volume of 1,093,487 t of fruit (SIAP, 2017; SIAP, 2019).
The Maradol papaya has a Cuban origin and was introduced in Mexico in 1977. It had an extended growth in the state of Veracruz in the last 20 years and currently prevails in the national market. Its features are productivity, post-crop handling strength and fruit quality. Nevertheless, it is prone to acquiring the Papaya ringspot virus (VMAP or PRSV-p) (FPS, 2009; Semillas del Caribe, 2017).

By the end of 2019, the state of Veracruz leads the national statistics as a main papaya producer; with a sown surface of 3,455 ha, an average yield of 32,759 $\mathrm{t} \mathrm{ha}^{-1}$, and a production of 112 mil t; followed by Michoacán and Colima, with yields greater that, in some occasions, outweigh the national average that amounts to $43.45 \mathrm{t}$ ha-1 (SIAP, 2010; SIAP, 2019).

The production cost for the placement of this crop is not smooth. Variability depends on the country zone involved and financial resources the producer has for technology management. $76 \%$ of production in the state of Veracruz is focused on the municipalities of Cotaxtla, Isla, Tierra Blanca, Soledad de Doblado and Tlalixcoyan, located mainly in the central region. The objective was to analyze the use of agricultural credit and the profitability of their papaya agroecosystem in the central region of the state of Veracruz.

\section{MATERIALS AND METHODS}

Research was made in the municipalities of Cotaxtla, Tierra Blanca, Tlalixcoyan, Soledad de Doblado, Manlio Fabio Altamirano, Puente Nacional and Actopan, Veracruz, Mexico. The first four are located between the first papaya producers, with $60 \%$ of production and $48 \%$ of the surface grown in the state (SIAP, 2017).

A mixed research was made with qualitative and quantitative variables through a poll, for which a semistructured questionnaire that considered open and closed questions, with Likert scale and multiple choice dichotomous-type answers, was applied. Questionnaire sections were: i) general producer aspects, ii) property features, iii) financial culture, iv) access to credits, v) crop management vi), training in papaya growing and vii) marketing.

In order to determine the sample size, the snowball nonprobability sampling method was considered (Briones, 1996). Its objective was to understand cultural or personal 
realities (Quintana-Peña, 2006). The choice criterion was being a papaya producer with a farming area established in any chose municipality and with availability to take part in the research. The final sample was of 114 producers located in the 45 towns in seven municipalities.

The information obtained was recorded in Excel $2007^{\circledR}$. A data exploratory analysis was made to obtain frequencies, central trend measures and charts in Excel $2007^{\circledR}$, together with measures and correlation in Statistica ${ }^{\circledR}$ version 7 (Spiegel \& Stephens, 2002).

\section{RESULTS AND DISCUSSION Identification and use of financing sources by papaya producers}

The following formal financing agencies are located in the area of influence for the seven municipalities of study in central Veracruz: Rural Financing (FR), an institution with branch offices in the cities of Veracruz and Xalapa. Only 10 producers (8.8\%), in three municipalities knew that FR is a potential financing source for the activity that they develop; two more (1.8\%) mentioned FIRA.

85 producers $(74.6 \%)$ stated that they did not know about any formal financing sources in support to their activity, albeit they stated that they did know Bancos Asociados a Cadenas Comerciales (BACC), who represent a semiformal source. The experience of these banks integrated to commercial chains, which rose in order to address sectors not covered by traditional banks is based on the marketing of their products through credit schemes (SHCP, 2012) and are not banks specialized in agricultural credit. Producers also consider agrochemical stores, the producer organization they are affiliated to and a microfinancing company located in the region as a potential financing source. As these businesses have grown, they represent a real resource source option and, according to the classification of Carranza (2007), they are internal production chain agents.

In four of seven municipalities, 26 producers (22.8\%) used some sort of financing or loan for addressing papaya crops. Six of these cases indicated obtaining financing from formal sources; out of these, three were granted by FR and two from commercial banking; in three of the four remaining cases, credits were granted by the BACC, which is a semi-formal source, and one chose to obtain cash through a credit card, with interest rates that are from 15.8 to $71.2 \%$, according to the banking institution (CONDUSEF, 2012).
Agrochemical stores and other inputs are other financing options used by six papaya producers (5.2\%) that fall within the internal production chain agents according to Carranza (2007). The input granted as a credit was provided by one of the companies located in the zones of influence and municipalities of study, practically in the beginning of the harvest, with the commitment of selling products and short installments that go from one week to one month. The term derives from fruit cut frequency ( 8 to 10 days), during the harvest performance period. Preference for granting financing is not limited to papaya or small producers. BANXICO (2012) states that commercial banking and input suppliers have been the main financing sources; i.e., suppliers provided $81.9 \%$ of financing in the last four-month period of year 2012.

$77 \%$ of interviewed producers stated that their own resources are those supplied to finance the establishment and maintenance of papaya growth. One of them states that "agriculture is uncertain; therefore, one cannot mortgage one's property". This common opinion among producers matches that of Landini (2011), who states that the trend in farmer objectives and preferences lies toward risk reduction, before profit maximization.

\section{General Aspects of Producers}

Out of the interviewed producers, $100 \%$ are male. They have an average schooling of 5.7 years; i.e. they have an incomplete primary education; in contrast the maximum degree of one producer is a post-graduate degree. The average age is of 48 years, within an age range of 21 to 74 years. This age interval is similar than the one identified in peach producers (33 to 75 years) in the State of Mexico (Larqué-Saavedra et al., 2009). INEGl (2009) states that the average age of independent producers in the agricultural sector is 51 years (Cabello, 2012). Un municipalities that comprise this research, 9.5\% of interviewed producers are older than 65 years of age.

A diversity of papaya-grown surface in the central Veracruz zone of 0.75 to 20 ha was identified, with a greater frequency in intervals lower than 3 ha, which represent $69 \%$ of the sample. These results match the sown area classification for papaya by Cerdas \& Sáenz (1993), where the greater percentage is located among "small producers" that grow more than one crop and have less than 4 ha.

The average time in the papaya growing activity is 17.7 years, within an age range of 21 to 52 years. Interviewed 
producers stated differences in crop handling, attributed to physical and financial resource availability enjoyed by each producer, as native varieties were predominant in the region until 20 years ago. "Yellow" or "coconut" varieties stand out. These did not require an intensive use of inputs and labor and were not that vulnerable to pests and diseases; although their disadvantage was their short shell life (Villanueva et al., 2007).

It is likely that producers have experience in handling native papaya varieties that did not require a strict handling and control. This may be one of the main reasons why the growth of the Maradol variety does not apply a smooth agronomic handling, as they adapt to the surface to be grown in each productive cycle and handling practices depending on financial resources available. This happened despite the fact that $28.1 \%$ of producers (32) stated having received training on plantations, production, health and packaging. "Yellow" papaya handling evidences were documented by the Papaya Interdisciplinary Group (GIP, 1995). Also, the application of integrated papaya handling suggested by GIP, was assessed in the Maradol variety by HernándezCastro et al., (2004).

\section{Production costs}

Production costs per papaya hectare by producers integrating the sample show a high variation between municipalities of study and even between towns of the same municipalities. Interviewed producers mentioned values from MX\$7500 in the municipality of Cotaxtla to $M X \$ 130,000$ in Soledad de Doblado, with a general mean of $M X \$ 68,292$ for the seven municipalities. Producers stated that activities demanding greater papaya crop investment are pests control and diseases (33.3\%), fertilization (25.4\%), cultural work (14.9\%) and land preparation (13.2\%).

For the 24 producers classified in the production cost interval from $\$ 86$ to $\$ 130$ thousand pesos, the average investment was of $\$ 103,958$ pesos that approach the
\$110 mil pesos reported by Sistema Producto Papaya del estado de Veracruz, A.C. (2011) in the technology package for the 2011-2012 productive cycle. Although 90 producers $(78.9 \%)$ reported costs under those considered for this civil partnership.

\section{Crop Yield}

According to information from interviewed producers, the average papaya yield estimated for the 20112012 period was of $79.5 \mathrm{t} \mathrm{ha}^{-1}$. The average yield per municipality varied from $41.8 \mathrm{t} \mathrm{ha}^{-1}$ in the municipality of Tlalixcoyan to $115 \mathrm{t} \mathrm{ha}^{-1}$ in the municipality of Puente Nacional. However, at an individual level, the interval is wider, as some producers stated obtaining yields of $10 \mathrm{t} \mathrm{ha}^{-1}$, in contrast with others who reported up to $160 \mathrm{t} \mathrm{ha}^{-1}$. This wide variation in yield may be explained due to differences in crop handling, which may also be associated to the availability of financial resources destined to growing, and the lack of technical knowledge or trust in technology that may be related to the high percentage of senior producers and, in other cases, limits for information access on financing sources or new crop handling technologies. This situation does not match the report for the southeast region of Mexico, where producers face several impediments that limit the papaya production growth. Financial, technology, infrastructure, training and organization problems cause a negative impact in the development of the agroalimentary chain for this fruit (Guzmán et al., 2008).

\section{Papaya Crop Profitability}

Even when the crop handling was varied, associated to production and physical and financial resource options available for the producers, econometric indicators report that the papaya crop is profitable (Table 1), as profits above $100 \%$ of investment costs per hectare are observed in all municipalities. This matches the statement of Guzmán et al. (2008) who concluded that, even when the technology level differed among producers in the financial assessment for papaya production, results show profitability.

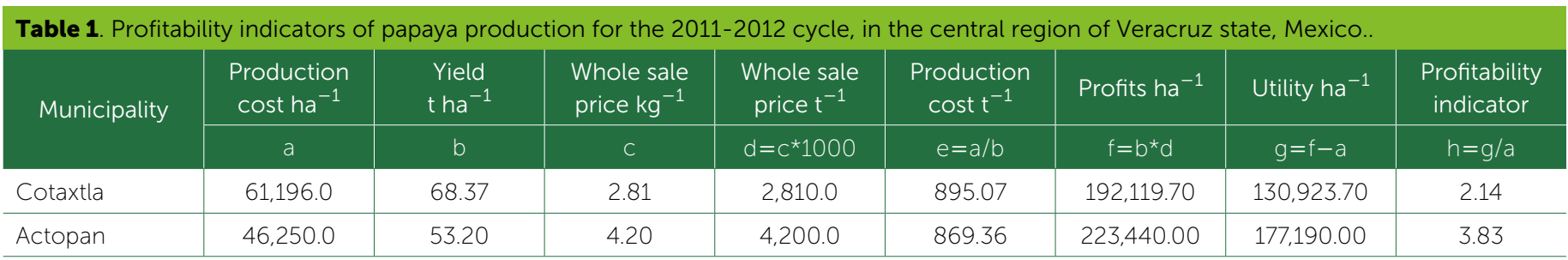


In an interview for La Jornada del Campo (2009), the director of FIRA mentioned that outside assessment made for FIRA by Universidad Autónoma Chapingo (UACh) and Grupo de Economistas y Asociados (GEA) showed that the credit itself increased producer risk in $24 \%$, technical assistance in $28 \%$ and $42 \%$ when going together. This statement must refer to those producers who obtained a FIRA credit and those who were provided with technical assistance. This situation was not observed in papaya producers in the central region of the state of Veracruz.

\section{CONCLUSIONS}

Something remarkable is that every four producers do not know the formal financing sources for those that may support their activity, reason why the use of the agricultural credit come from formal sources is very low among papaya producers in the central region of the state of Veracruz; the main financing source is their own financial resources. Other semi-formal and informal financing sources are input suppliers, friends, family and BACC.

There is a wide variety in production costs per hectare in the growth of papaya, which is associated to the technology level with handling practices that demand greater investment and is finally reflected in the understanding of the crop. Even with low access to financing, the papaya crop is profitable.

\section{ACKNOWLEDGMENTS}

To papaya growers in the seven sampled municipalities for their trust and kind and attentive participation. To Colegio de Postgraduados, Veracruz Campus, for the financial support and granted facilities.

\section{REFERENCES}

BANXICO (Banco de México) (2012). Evolución del financiamiento a las empresas durante octubre-diciembre 2011. http://www. banxico. org.mx/informacion-para-la-prensa/comunicados/sectorfinanciero/financiamiento-empresas/\%7BF96331BA-586C-3FDC0C80-FD897D6180DB\%7D.pdf. Consultado 4 de junio de 2012.

Briones, G. (1996). Metodología de la investigación cuantitativa en las ciencias sociales. Instituto Colombiano para el Fomento de la Educación Superior. ICFES. Bogotá, Colombia. p. 58.

Cabello V. M. A. (2012). Edad y crédito agropecuario. El Economista, $1^{\circ}$ de noviembre, México, Subdirector de Diseño de Programas en FIRA. http://eleconomista.com.mx/columnas/ agro-negocios/2012/11/01/edad-credito-agropecuario. 15 de diciembre de 2012.

Carranza, C. F. (2007). Probabilidad de acceso al crédito en productores agropecuarios: estimación con variable dependiente censurada y muestras truncadas. Revista Centroamericana de Ciencias Sociales 4 (2): 103-131.
CONDUSEF (Comisión Nacional de Protección a los Derechos de los Usuarios de Servicios Financieros) (2012). Comparativo de tarjetas de crédito, crédito hipotecario y crédito de nómina. http://www.condusef.org. mx/comparativos/index.php/ bancos. Consultado 8 de junio de 2012.

FAO (Food and Agriculture Organization of the Nations United's) (2009). El desafio de la tecnología. Foro de Expertos de Alto Nivel. 12-13 octubre. Roma, Italia. http://www.fao.org/ fileadmin/templates/wsfs/docs/Issues_papers. Consultado 10 de octubre de 2012.

FAOSTAT (Food and Agriculture Organization of the Nation United's) (2017). FAO Statical Database. http://faostat.fao.org/site/342/ default.aspx. 10 de marzo de 2020

FPS, A.C. (Fundación Produce Sinaloa, A.C.) (2009). Paquete tecnológico para la producción de papaya en Sinaloa. MuñozCano R. M. y Martínez A. C. O. http://www.fps.org.mx/ divulgacion/attachments/article/813. Consultado 6 de agosto de 2012

FR (Financiera Rural). (2011). Reglas de operación. www.financierarural. gob.mx. Consultado octubre de 2011.

Guzmán R. E., Gómez A. R., Pohlan H. A. J., Álvarez-R. J. C., Pat F. J. M. y Geissen V. (2008). La producción de papaya en Tabasco y los retos del desarrollo sustentable. El Cotidiano 23: 99-106.

GIP (Grupo Interdisciplinario del papayo). Flores-Revilla C., GarcíaPérez E., Nieto-Ángel, Téliz Ortíz D. and Villanueva-Jiménez J. A. (1995). Integrated management of papaya in Mexico. Acta Horticulturae 370:151-158

INEGI (Instituto Nacional de Estadística Geografía e Informática) (2009). Prontuario de municipios. http://www.inegi.org.mx/ sistemas/mexicocifras/datos-geograficos/30/pdf. Consultado enero de 2012.

Hernández-Castro E., Villanueva-Jiménez J.A., Mosqueda Vázquez R. y Mora-Aguilera A. (2004). Efecto de la Erradicación de Plantas Enfermas por el PRSV-P en un Sistema de Manejo Integrado del Papayo (Carica papaya L.) en Veracruz, México. Revista Mexicana de Fitopatología 22 (3): 382-388.

La Jornada del Campo. (2009). Solo 30 por ciento de productores acceden a crédito. Abril 17. http://www.jornada.unam. mx/2009/04/17/delcampo.html. Consultado 15 de febrero 2010 .

Landini, F. (2011). Racionalidad económica campesina. Mundo Agrario. Facultad de Humanidades y Ciencias de la Educación de la Universidad Nacional de La Plata, Argentina. Memoria Académica 12(23) 27 p. http://www.memoria.fahce.unlp.edu. ar/art_revistas/pr.5045/pr.5045.pdf. 12 de marzo de 2012

Larqué-Saavedra, B. S., Sangerman-Jarquín S. D. M., Ramírez-Valverde B., Navarro-Bravo A. y Serrano-Flores M.E. (2009). Aspectos técnicos y caracterización del productor de durazno en el Estado de México, México. Agricultura Técnica en México, 35 (3): 305-313.

Quintana-Peña, A. 2006. Metodología de investigación científica Cualitativa. Quintana Alberto y Montgomery W. (Eds) En: Psicología: Tópicos de actualidad. Lima: UNMSM pp. 5859. http://es.scribd.com/doc/3634305/Metodologia-deInvestigacion-Cualitativa-A-Quintana.

Semillas del Caribe (2017). Papaya. www.semillasdelcaribe.com.mx. Consultado marzo de 2018 
SHCP (Secretaria de Hacienda y Crédito Público/Banca de Desarrollo) (2009). Banca de desarrollo. www.secretariadehaciendaycreditopublico/bancadedesarrollo.gob.mx. Consultado febrero 2010

SHCP (Secretaria de Hacienda y Crédito Público) (2012). Unidad de Banca, Valores y Ahorro. www.apartados.hacienda.gob.mx. Consultado diciembre 2013.

SIAP (Servicio de Información Agroalimentaria y Pesquera) (2010). Cierre de la producción agrícola por cultivo. www.siap.gob.mx. marzo de 2012.

SIAP (Servicio de Información Agroalimentaria y Pesquera) (2017). Cierre de la producción agricola por cultivo. www.siap.gob.mx. marzo de 2018

SIAP (Servicio de Información Agroalimentaria y Pesquera) (2019). Cierre de la producción agrícola por cultivo. www.siap.gob.mx. marzo de 2020.

Sistema producto papaya del estado de Veracruz, A.C. 2011. www.productopapayaveracruz. org. Consultado abril de 2011.

Spiegel, M. R., y Stephens L. J. (2002). Estadística. L. E. Pineda A. (trad.) 3a Edición. McGrawHill/Interamericana (Ed.). México, D.F. 531 p

Villanueva-Jiménez, J. A., Hernández-Castro E., Ávila C., Osorio-Acosta F., Teliz-Ortíz D., MoraAguilera A. y García-Pérez E. (2007). El papayo, estado del arte de la investigación y la transferencia de tecnología. Parte 1 de 2. Agroentorno 87:19-22.

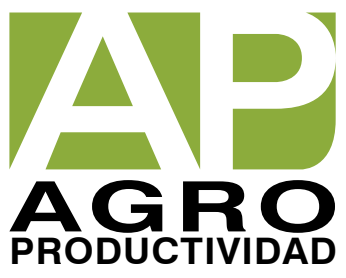

